\title{
K4D's Work on the Indirect Impacts of COVID-19 in Low- and Middle- Income Countries
}

Evert-jan Quak

Institute of Development Studies (IDS)

30 June 2021

\section{Contents}

1. Introduction

2. Summary

3. Quantitative overview

- Thematic coverage.

- Types of requests and outputs.

- Requesting cadres and intended use of reports.

- Geographical scope.

- Feedback and citations.

4. Illustrative overview of findings

- Health.

- Economy.

- Conflict and governance.

- Social inclusion.

- Interventions.

5. Conclusions

Annex: List of K4D resources on indirect COVID-19 impacts 


\section{Introduction}

The Knowledge, Evidence and Learning for Development Programme (K4D) provides access to all FCDO staff to recent research and evidence. The programme has produced over 1000 rapid evidence syntheses (helpdesk reports), 40 emerging issues reports, and run 40 learning journeys. Much of K4D's body of evidence responds to core, crosscutting development challenges.

The rapid nature of the K4D service and its flexibility means that it was able to bring together new and emerging evidence required for the COVID-19 response very quickly, in particular through developing regular evidence summaries for FCDO and external partners on COVID-19 and health, and another set on COVID-19 conflict and governance issues. This report looks at K4D's work on the indirect impacts of COVID-19 for Low- and Middle-Income Countries (LMICs), which contains a total of 49 reports and 12 Learning Products. These K4D outputs span the period from the end of February 2020 until the end of May 2021.

This report is not an in-depth nor exhaustive analysis of the many indirect impacts of the pandemic on LMICs. The content is purely based on the requests from FCDO to the K4D services on this topic, and as such can only give an illustrative overview of the findings from these requests. Furthermore, insights are also taken from the data that K4D collects for each request based on the information provided by advisers and FCDO (e.g. purpose of request, adviser's cadre), hence, the data is limited to the information available to the K4D team at the time of the request and the level of details available may vary from one request to the other.

The selection of relevant K4D outputs on the pandemic's indirect impacts was based on an extensive search in the K4D repository on titles and research questions. The Annex shows all K4D outputs included in this report. The purpose of this report is to inform FCDO about some of the specifics of their requests on the indirect impacts of COVID-19, in general. This report will also be used as input for a K4D-FCDO learning event that takes place on the $6^{\text {th }}$ of July 2021. During the event learning and evidence trends will be discussed and how evidence and learning informed decision making on policy and programming.

\section{Summary}

- Of the 49 requested K4D outputs on the pandemic's indirect impacts in LMICs (included in this report), the majority cover the general themes of "economy", (donor/government) "interventions", and "social inclusion". Most of them are K4D rapid reviews (helpdesk reports).

- The vast majority of the requested outputs are analytical, which refers to enquiries framed as specific research questions that need to be answered by compiling and linking piece by piece the evidence. The purpose mostly mentioned by the requesters is for specific programmes.

- A high number of requests came from the Prosperity Fund COVID-19 Evidence \& Learning Initiative (Learning Journey), which might explain the emphasis of requests on economic development and the focus on some middle-income countries.

- The K4D reports have received higher feedback responses than other K4D reports and have been cited by major knowledge hubs, reports, books and academic journals. The majority of requesters that filled in the evaluation form gave high scores for quality. 
- This report shows the interrelationship between the indirect impacts of COVID-19 which need coherent, interdisciplinary, and transformative responses and approaches.

\section{Quantitative overview}

\section{Thematic coverage}

Based on the specific research questions for each request, seven clusters of key broad themes could be identified regarding the indirect impacts of the pandemic on LMICs. Figure 1 shows the distribution of the reports per theme. The reports' research questions focus mainly on the pandemic's impact on the economy (11), interventions (international responses) (11), social inclusion (10), health (9), and conflict and governance (9). Themes with less coverage are water (4) and education (3). Note that some of the 49 reports had a focus on multiple themes.

Figure 1: Share of reports per theme

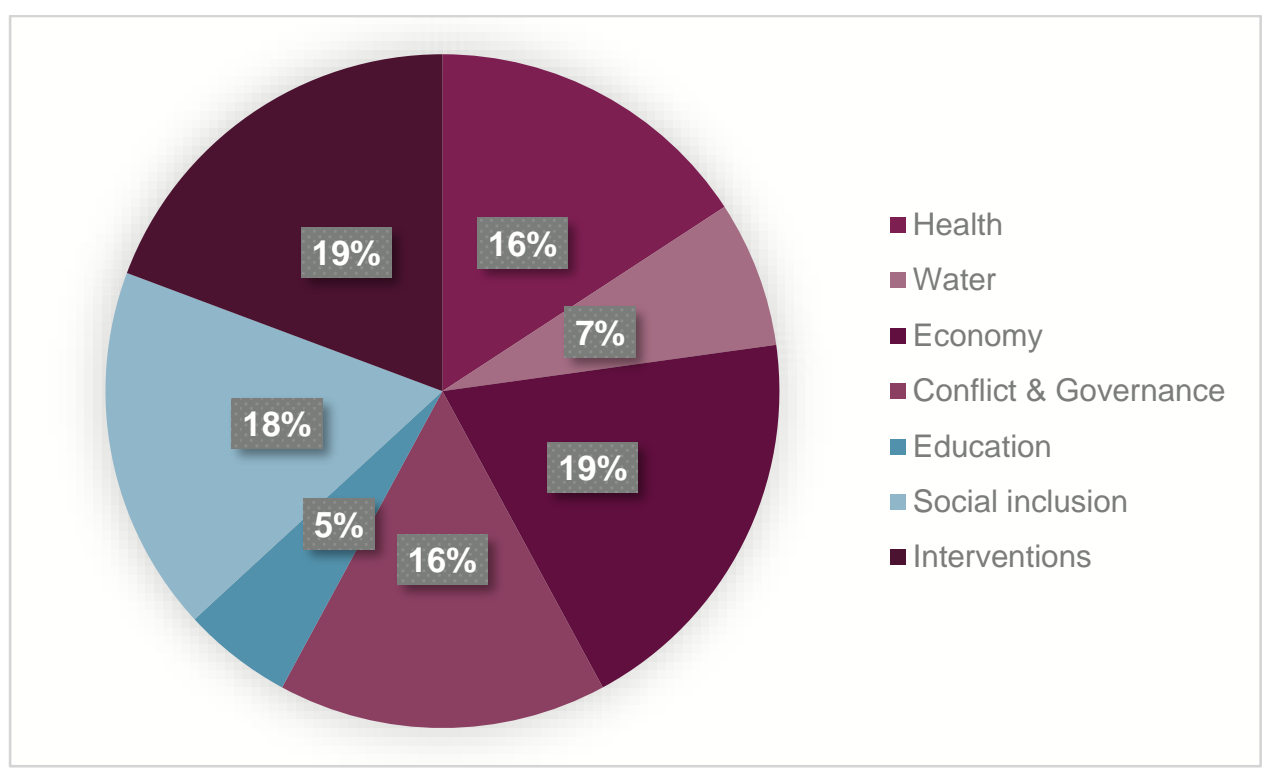

The full spectrum of indirect impacts covered by K4D research outputs on COVID-19 can be seen in Figure 2. This Figure gives a mapping of the different topics considered under the seven broad themes, the mapping is non-exhaustive (as other indirect impacts of COVID-19 exist) and does not indicate the importance of these impacts, it simply provides a descriptive representation of the COVID-19 requests coming from FCDO.

For the indirect health impacts the requests can be broadly split into those that looked at health systems (the implications on finance and private sector involvement; tracking and surveillance systems; and essential health services, such as immunisation and maternal and sexual reproductive health), and those that looked at other diseases in relation to COVID-19, such as the impact on specific tropical and infectious diseases and specifically on non-communicable diseases. A very small number of reports also say something about the impact on nutritional intake, although this was always a sub-topic within a larger report.

The requests on the economic impacts of the pandemic focus on how Global Value Chains (GVCs), employment, and progress made towards inclusive economic growth are affected by the 
measures to control the spread of the virus. Some have a specific focus on the informal sectors. One specific report looks at the opportunities for LMICs to produce their own vaccines.

Most of the conflict and governance requests looked at the implications of the pandemic on governance (public finance; leadership and politics; accountability and state-citizen relations). The governance focus links well with the reports about interventions, which mainly focus on how to achieve a building back better agenda for greener, more resilient, and more inclusive development outcomes. Some requests looked specifically at the international responses and how building back better could be linked with soft power and a mutual prosperity approach. Some requests also looked at the implications of the pandemic on conflict and security, with one report having a specific focus on the potential opportunities for extremists' recruiting.

Some reports related to the Learning Journey on Water Security looked at the implications on access to water for the urban poor and the importance of stimulating WASH in schools. The education requests were looking mainly at girls' education and could be linked with some requested reports on the impact on youth and children (e.g. girls' life skills and child labour). Several reports also highlighted the indirect impact on women (e.g. on their participation in decision-making processes and implications on their employment in GVCs). Very few reports say anything explicitly about the indirect impacts of the pandemic on people with disabilities.

Some general observations can be made:

- Social inclusion has a strong focus on women and youth/children/girls, where other vulnerable groups have been mentioned to a far lesser extent.

- No requests specifically focused on agriculture, food and nutrition security, or food systems.

- Most of the early literature does not have a focus on COVID-19 as such but tries to learn from evidence and responses to earlier pandemics or crises. 



\section{Types of requests and outputs}

Figure 3 shows that most outputs on COVID-19 during the study period were Helpdesk reports (HDRs), while there were 5 more substantive Emerging Issues Reports (EIRs) requested. Other outputs include the sets of COVID-19 Evidence Summaries ${ }^{1}$ on (1) Health and (2) Conflict and Governance, but also include some summary reports from events organised within relevant Learning Journeys. These summary reports came from three Learning Journeys: Health System Strengthening, Water Security, and Prosperity Fund COVID-19 Evidence \& Learning Initiative. The Learning Products included blog posts, infographics, and slide packs of presentations. Figure 4 shows the distribution of these outputs per thematic cluster.

Figure 3: K4D outputs

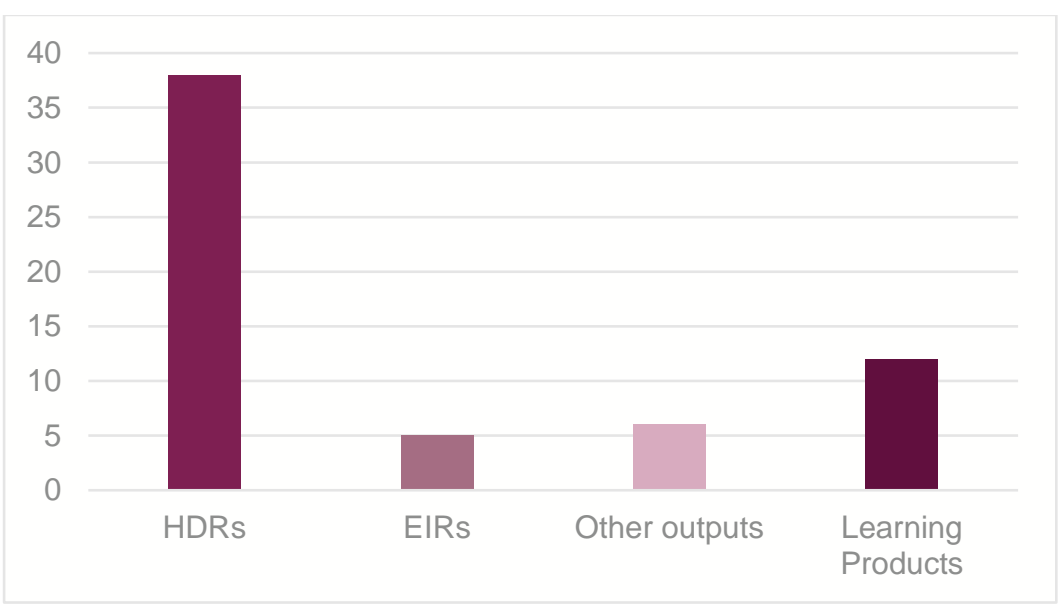

Figure 4: Outputs per thematic cluster

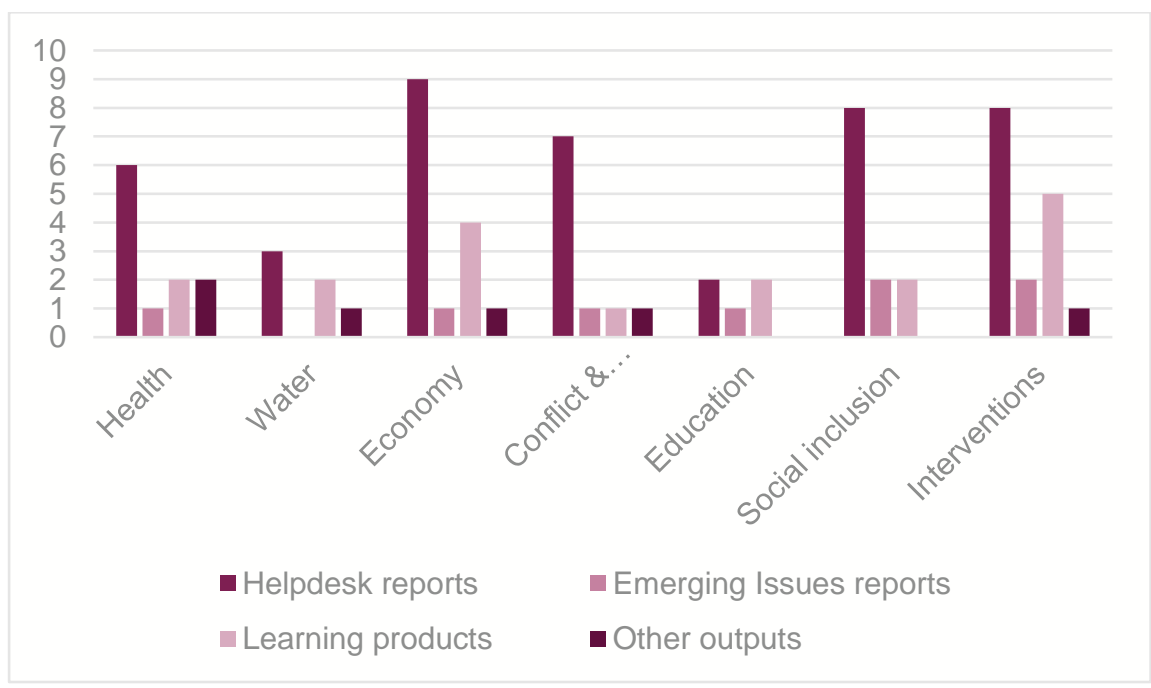

K4D records different types of requests and data about each request and the adviser making the request (the level of detail on each request can vary to ensure easy access to the helpdesk

\footnotetext{
1 The COVID-19 Health Evidence Summaries (HES) and Conflict \& Governance Evidence Summaries list relevant resources that are searchable through the K4D COVID-19 search engine. This report counts these summaries as two K4D outputs although the HES for example produced over 100 summaries.
} 
services, making it more difficult to make in-depth comparisons). Table 1 shows that most requests were analytical (36), which often relates to the high number of requests to analyse the evidence of indirect impacts during other pandemics and crises to learn from it in the context of COVID-19, as empirical evidence from the current crisis is limited, particularly during the earlier stages. Six requests could be categorised as lessons learned from evaluations (e.g. engaging girls in life skills interventions at a distance). There were 5 requests to provide an overview of the literature around an area of interest (including the COVID-19 Evidence Summaries) and 3 donor/government practice requests (e.g. approaches of tracking indirect health impacts of pandemics).

Seven out of 49 reports were issued for internal use only and 1 partly as the full report on the impact of the pandemic on the Better Health Programme (Prosperity Fund) is not publicly available but a policy brief with the main policy findings will be available to the wider public.

Table 1: Types of requests

\begin{tabular}{|l|l|}
\hline Type & Description \\
\hline $\begin{array}{l}\text { Donor/Government } \\
\text { practice (3) }\end{array}$ & $\begin{array}{l}\text { Enquirer looking for examples of how donors/governments have } \\
\text { approached a particular issue, or the type of work they have done in a } \\
\text { particular area of practice. Typically limited to donor material. }\end{array}$ \\
\hline Analytical (36) & $\begin{array}{l}\text { Enquiry is framed as a specific research question, which can be narrow } \\
\text { or broad. The answer may not be ready-made and may have to be } \\
\text { compiled by piecing together and making links between different strands } \\
\text { of literature. Typically requires looking at multiple types of literature. }\end{array}$ \\
\hline $\begin{array}{l}\text { Overview of } \\
\text { literature (5) }\end{array}$ & $\begin{array}{l}\text { Enquirer wants to know what the recent literature has to say on a given } \\
\text { issue. Usually an 'area of interest' rather than a specific research } \\
\text { question. Typically limited to academic literature and leading policy } \\
\text { papers. }\end{array}$ \\
\hline Evaluation/lessons \\
learned (6) & $\begin{array}{l}\text { Enquirer is looking for a summary of the main practical lessons learned } \\
\text { from evaluations or an overview of best practice policy in a particular } \\
\text { area. Increasingly this category might include evidence of impact of } \\
\text { interventions in a particular area. Typically limited to donor evaluation and } \\
\text { policy literature. }\end{array}$ \\
\hline Mapping (0) & $\begin{array}{l}\text { Enquirer is looking for basic information on organisations or individuals } \\
\text { and their activities in a particular area of work. Typically presented in a } \\
\text { tabular format. }\end{array}$ \\
\hline
\end{tabular}

\section{Requesting cadres and intended use of reports}

A total of 29 requests came from 10 different cadres, with the most coming from the Health and Education cadres. Outside the cadres, it was mainly the Prosperity Fund (due to the Learning Journey) that requested K4D services on the indirect impact of COVID-19 for LMICs. The high number of requests from the Prosperity Fund is reflected in the number of requests related to economic impacts and building back better interventions. Requests also came from two embassies (Senegal and Ethiopia) and the Human Rights and Democracy team. 
Figure 5: Cadres (DFID/FCDO)

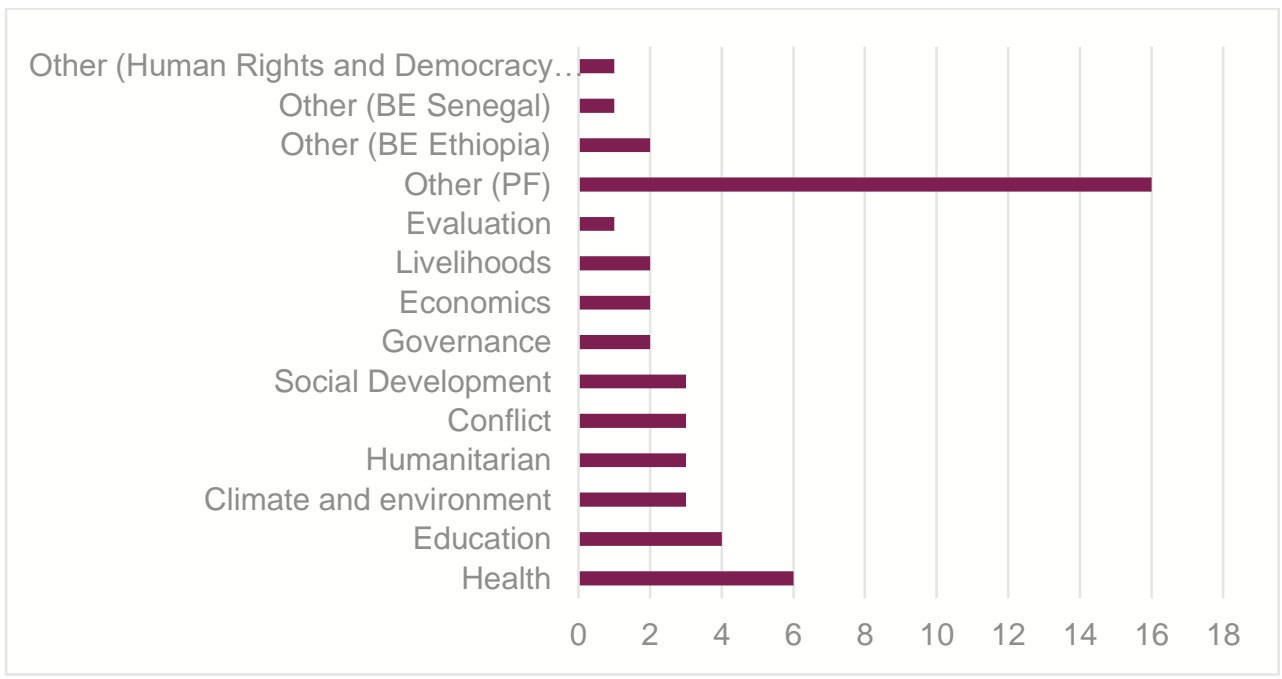

The intended use of the K4D reports could be determined from the recorded purposes of the requests. Six types of intended use have been determined as Table 2 shows. Most are emerging issues (22) which relates to ways to understand the potential impacts of the pandemic in specific areas. 14 requests related directly to specific programmes, with the purpose to use the reports to feed into discussions to adapt programmes to the new realities. The purpose of six reports could be traced to feed into policies or strategies. Some reports (3) mentioned they wanted to test an assumption (for example on the importance of public finance management interventions during a crisis), while another 3 reports supported Learning Journeys (e.g. event summary reports) and one report's purpose was to shed light on changing directions of research.

Table 2: Types of FCDO purpose for requests

\begin{tabular}{|l|l|}
\hline Type & Description \\
\hline Emerging issue (22) & $\begin{array}{l}\text { The report is intended to help the agency or individual get to grips with the } \\
\text { basics of an issue that has only recently got on the agenda (or is not yet). These } \\
\text { queries are a starting point for developing thinking in this area and may feed into } \\
\text { the policy cycle at the stage prior to formal policy development. }\end{array}$ \\
\hline Policy development (6) & $\begin{array}{l}\text { The report is meant to inform the development of formal policy and strategy } \\
\text { (often in the form of a written policy paper) on a given area. Typically, these type } \\
\text { of queries come from policy or research teams in headquarters. }\end{array}$ \\
\hline Programme planning (14) & $\begin{array}{l}\text { Typically, these queries come from country offices and are intended to feed } \\
\text { directly into country-level programming, business case and planning. They may } \\
\text { be specifically intended for influencing partners and government or learning } \\
\text { lessons from practice in other countries. They are at the implementation end of } \\
\text { the policy cycle. }\end{array}$ \\
\hline Test assumption (3) & $\begin{array}{l}\text { The report is intended to help the agency or individual to test an assumption } \\
\text { based on available evidence. }\end{array}$ \\
\hline Supporting LJ (3) & $\begin{array}{l}\text { This is not a specific K4D request for a report, but the report is the product of } \\
\text { events organised during a Learning Journey. These are summary reports to } \\
\text { capture the discussions, outcomes, and action points. }\end{array}$ \\
\hline Research (1) & $\begin{array}{l}\text { Typically, these requests come from research teams in headquarters to } \\
\text { understand knowledge gaps and emerging research areas. }\end{array}$ \\
\hline
\end{tabular}




\section{Geographical scope}

Most of the requests do not have a focus on a specific country or region but look to LMICs in general. Due to the high number of requests from the Prosperity Fund, 14 requests were exclusively focusing on Middle-Income Countries (MICs). Of the 10 reports that looked into specific regions or countries, most were focusing on Africa as Figure 6 shows.

Figure 6: Regional specific requests

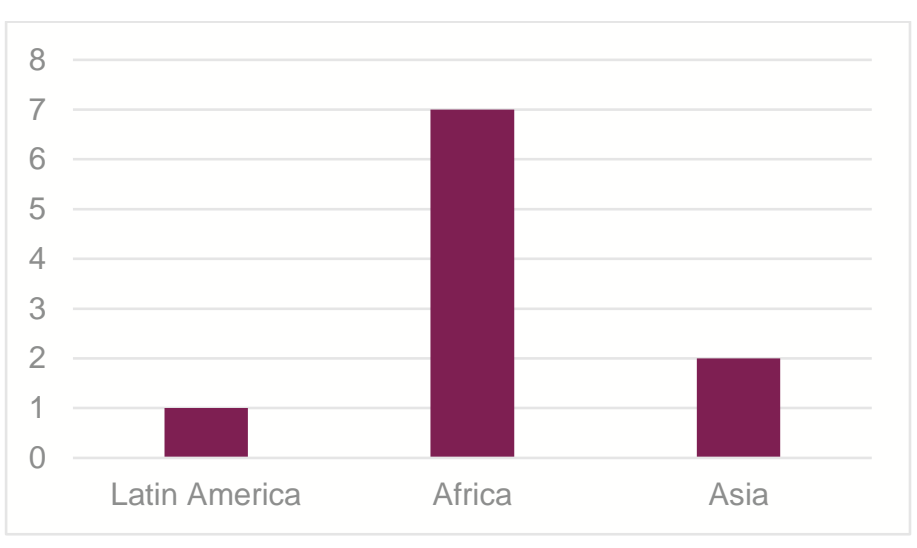

Some requests have a focus on specific countries, although most of these reports look at more than one country. As Figure 7 shows, Tanzania and Indonesia are focus countries in three reports.

Figure 7: Focus countries of requests

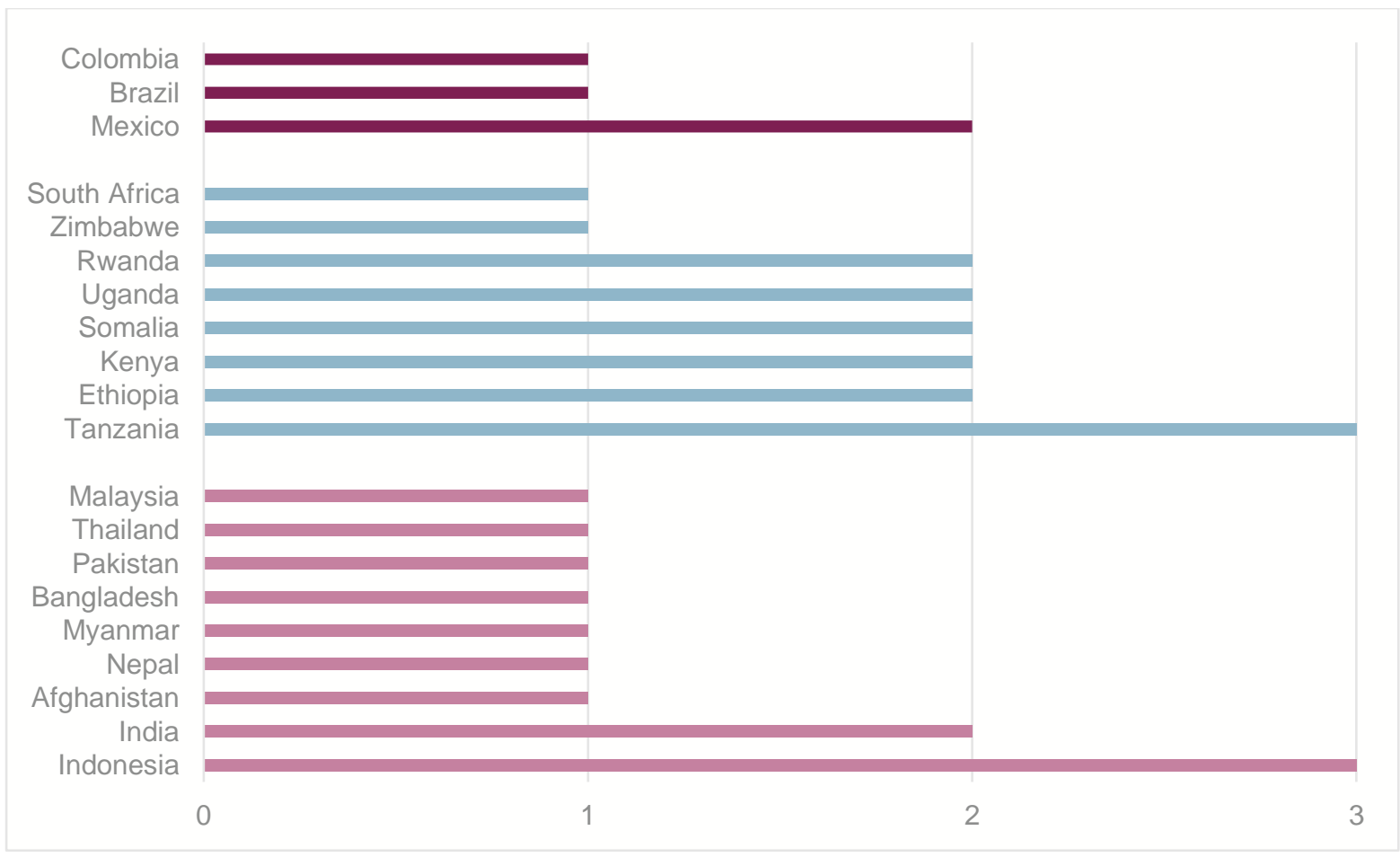




\section{Feedback and citations}

The reports on the indirect impact of COVID-19 have received higher feedback responses than other K4D reports and have been cited by major knowledge hubs, reports, books and academic journals, particularly at the start of the pandemic when information was in high demand due to uncertainties. $28.6 \%$ of the requesters filled in the feedback form and $44.9 \%$ of the reports were cited in other works, including in 29 journal articles. The majority of requesters were overall giving high scores for quality as Figure 8 shows.

Figure 8: Scores for quality of the K4D reports from requesters.

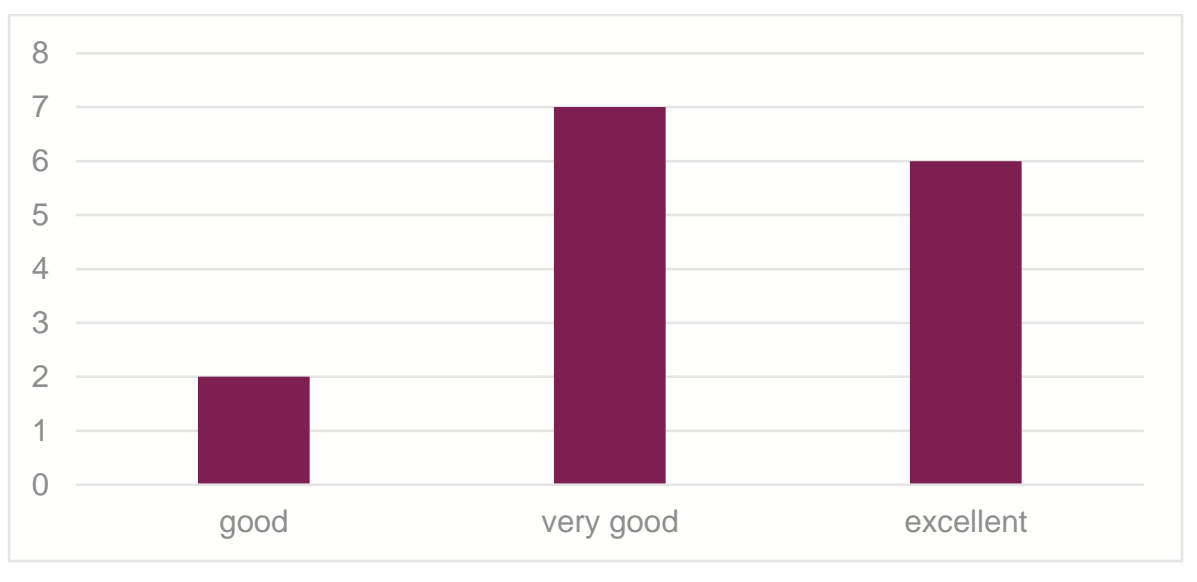

\section{Illustrative overview of findings}

This section of the report gives some illustrative insights from the findings as mentioned in the K4D outputs. This overview is not exhaustive and complete and only covers some of the main topics as mentioned in Figure 2.

\section{Health}

- The K4D reports find that COVID-19 has significantly disrupted, suspended and diverted resources from essential health services in LMICs. This could cause a secondary health crisis and reverse decades of progress in global health. Health systems will be stretched further with deployment of COVID-19 vaccines, the reports mention. ${ }^{2}$

- Evidence from previous pandemics and epidemics shows that the collapse of prevention and health promotion services limited children's access to immunization services, as well as pregnant women to maternity hospitals where they can have their children safely. ${ }^{3}$ Significant declines in vaccinations were observed and maternal and child health declined significantly, during and after the Ebola epidemic in West Africa, for example. Several sources of

\footnotetext{
2 See more in HDR1007 "Protecting and promoting systems for essential health services during rollout of COVID19 tools" by Kerry Millington.

${ }^{3}$ One of the reports looked at Tanzania: HDR825 "Maternal and sexual reproductive health situation in Tanzania" by Kerina Tull.
} 
information also confirmed that treatment of health conditions, such as HIV/AIDS and TB, decreased during the Ebola crisis. ${ }^{4}$

- The impact of COVID-19 on health and health services in countries where transmission of the virus has been high could continue to increase over the next years by an extended period of economic difficulty which is likely to create new patterns of inequality and exclusion accompanied by increased health care needs at a time when governments are likely to experience serious resource constraints.

- Chronic Non-Communicable Diseases (NDC) such as diabetes and high blood pressure are a major cause of severe illnesses caused by COVID-19 that put extra pressure on health services and can have an impoverishing impact on families. An effective strategy for reducing the risk of developing an NCD is an important element in a strategy for protecting poor households. ${ }^{5}$

- Some innovative adaptive measures have mitigated some of the impact of the pandemic and presented opportunities for integrated service delivery such as testing for COVID-19 and other diseases. The reports also show that investment in effective and efficient service delivery for COVID-19, essential health services, and well embedded surveillance and tracking systems will not only support the response to and recovery from COVID-19 but also strengthen the resilience of health systems to future challenges. ${ }^{6}$

\section{Economy}

- In general, the K4D reports find that economies and livelihoods in LMICs are negatively affected by major infectious disease outbreaks, in both short term and in the longer term after the crisis has ended. ${ }^{7}$

- For the longer term, the high costs of the responses have increased fiscal stresses which are exacerbated by diminished tax revenues due to a sharp decline in economic growth.

- In the shorter term, official responses against the spreading of the virus combined with fear-induced behaviour changes, such as avoiding workplaces and markets, causes economic and employment disruptions, often resulting in household incomes to be decreased.

- More directly, livelihoods also face lower incomes to death, sickness, and the additional expenses to healthcare. Poorer households are especially affected as they have limited means to cope.

\footnotetext{
${ }^{4}$ See for example: HDR836 "Enhancing insights into indirect health impacts of previous health emergencies and COVID-19 in Africa" by Kerina Tull (internal document) and HDR837 "Enhancing insights into indirect health impacts of previous health emergencies and COVID-19 in LMICs" by Kerina Tull (internal document). 5 See more in EI41 "Addressing NCDs during COVID-19 and beyond: implications for the Better Health
Programme" by Jennifer Constantine and Gerald Bloom (internal document).

${ }^{6}$ See more in HDR1007 "Protecting and promoting systems for essential health services during rollout of COVID19 tools" by Kerry Millington and HDR837 "Enhancing insights into indirect health impacts of previous health emergencies and COVID-19 in LMICs" by Kerina Tull (internal document).

7 See more in HDR811 "Impacts of COVID-19 on Inclusive Economic Growth in Middle-income Countries" by Brian Lucas and HDR756 "Secondary impacts of major disease outbreaks in low- and middle-income countries" by Brigitte Rohwerder.
} 
- Some sectors are more severely hit, in particular the tourism sector. In terms of sector differences, construction was also harder hit by the initial mobility restrictions than for example agriculture. The Colombia report, for example, mentions that the construction sector contracted by $30.5 \%$ in the second quarter of $2020 .{ }^{8}$

- GVCs also have been disrupted, again some more than others. For example, where the value chain depends on timely air travel (e.g. fresh produce such as cut flowers) or lenient value chains without much flexibility (e.g. automotive value chains) there were more disruptions. Responses to the crisis focus on resilience building which could change supply chains due to spreading risks and reshoring production. Some countries could benefit others could lose out due to changes in GVC governance. ${ }^{9}$

- Some K4D reports looked specifically into the employment impacts. A novel effect of this crisis is that job loss has been more intense among self-employed workers than among wage earners, and deeper among informal than formal workers. The impact from COVID-19 on the labour market has been greatest for those in precarious employment, at an early stage in their career or engaged in the informal sector. Increasing unemployment rates due to COVID-19 measures will likely push more people into the informal economy, potentially displacing workers. ${ }^{10}$

- The informal sector has suffered from the consequences of lockdown measures that have reduced mobility and transport, curtailed informal markets and small-scale enterprises often run by independent contractors. Marketers work in crowded conditions and cross-border informal traders have had to come to terms with irregular enforcement of travel bans and cross-border COVID-19 testing. These workers have little to fall back on and have no access to social protection measures. ${ }^{11}$

- One solution to employment problems could be vocational training systems. However, as one report shows, these could face multiple challenges in the post-COVID era. LMICs need to carefully consider how to smooth transition young people into work, especially now many have had their education disrupted or who have had a gap before entering the labour market due to the pandemic. These trainings need to be linked with longer term trends of automation and the transition to a green economy. ${ }^{12}$

- The pandemic could increase opportunities for some LMICs for manufacturing vaccines. Evidence from southeast Asia and Latin America shows that government support is essential. The country vaccine market in LMICs has historically been high volume, low profit traditional vaccines, which is not especially attractive to most vaccine-producing multinational companies. Although vaccines development and manufacturing may cost public money, the

\footnotetext{
8 See HDR971 "The economic impact of COVID-19 in Colombia" by Laura Bolton.

9 See more in HDR874 "The COVID-19 pandemic and the future of Global Value Chains (GVCs)" by Evert-jan Quak.

10 See HDR956 "COVID-19 impact on employment and skills for the labour market" by Sue Enfield.

11 See more in HDR890 "The Informal Sector and COVID-19" by Kelbesa Megersa and on the informal sector in Zimbabwe in HDR815-16 "Impacts of COVID-19 regulatory measures on small-scale and informal trade in Zimbabwe" by Roz Price.
}

12 See HDR957 "How can middle-income countries improve their skills systems post-COVID-19?" by George Herbert. 
potential to provide benefits to better health in society could reduce longer term economic costs. ${ }^{13}$

\section{Conflict and security}

- The K4D reports on the indirect impacts on conflict, security, and violence show that epidemics are widely considered to amplify conflict and violence due to increased grievances, divides, fragility. However, emerging findings from K4D reviews on the pandemic suggest that a rethink is needed on the importance of human security, with the risks, thus far, primarily affecting individuals rather than states. For example, the most frequently reported form of violence directly related to COVID-19 is rapidly increasing sexual and domestic abuse in every continent of the world. ${ }^{14}$

- The use of military and police in COVID-19 responses might have increased distrust in some places, though most protests do not appear to have had significant impacts so far on government policies. Historic examples highlight that anti-government protests should be monitored in regard to political instability, especially when related to hunger, economic scarcity, and resource competition, risk factors that are increasing. ${ }^{15} \mathrm{~A}$ report on the security implications for the Eastern African region mentions that the pandemic may also be used by some leaders to push their targets in ways that worsen conflict, as they crack down on domestic opposition or intensify conflicts on the presumption that they will get away with it while the international community is preoccupied with the pandemic. ${ }^{16}$

- Overall, there is pessimism about the impact of COVID-19 on national peacemaking and existing peace processes; peacekeeping operations were initially scaled back due to COVID19 adaptations. ${ }^{17}$ While there are widespread warnings of state and non-state armed actors taking advantage of the crisis to pursue their interests and to expand their operations and popularity, evidence of this is limited so far. One K4D report found limited evidence on past pandemics, radicalisation and violent extremism. Evidence was, however, identified on the impact of disasters on radicalisation and violent extremism that may warrant further exploration. ${ }^{18}$

- The K4D reports show the importance of context specific conflict-sensitive analysis for ensuring policy responses and adaptions do not undermine social tensions and do not miss opportunities to positively address conflict dynamics.

\footnotetext{
${ }^{13}$ See more in HDR974 "Economic impact of local vaccine manufacturing" by Kerina Tull.

${ }^{14}$ See EI34 "COVID-19, governance, and conflict: emerging impacts and future evidence needs" by Sian Herbert and Heather Marquette.
}

15 See EI34 "COVID-19, governance, and conflict: emerging impacts and future evidence needs" by Sian Herbert and Heather Marquette.

${ }^{16}$ See more for Eastern Africa HDR847 "COVID-19 in Eastern Africa: impact analysis on conflict and security" by Kelbesa Megersa.

17 See EI34 "COVID-19, governance, and conflict: emerging impacts and future evidence needs" by Sian Herbert and Heather Marquette.

18 See HDR808 "The COVID-19 pandemic and response on violent extremist recruitment and radicalization" by William Avis. 


\section{Governance}

- K4D's rapid literature reviews looked at the implications for public finance from the perspective of public finance management (PFM) and tax revenues. ${ }^{19}$ The overall conclusion is that PFM reforms ${ }^{20}$ have played a significant role in setting up effective, efficient, and transparent fiscal stimulus packages (e.g. cash transfers, public work programmes) measures during and after economic crises. It is important to separate short-term PFM reforms or responses that allow adaptations of the fiscal framework to let fiscal responses (e.g. stimulus packages) happen during a crisis, and longer-term PFM reforms after a crisis that prevent and better equip governments for a potential financial crisis. ${ }^{21}$

- With economic conditions deteriorating, tax agencies and departments increasingly could face compliance risks, including tax arrears (i.e. taxes due but not paid), loss-reporting companies, and the cash economy. At the same time, agencies could be overstressed due to additional support and assistance to taxpayers combined with potential budget cuts as governments struggle with increasing fiscal pressures. ${ }^{22}$

- Emerging evidence mentioned in some K4D reports also suggests a number of ways in which COVID-19 may be shaping state-citizen relations, particularly where they are already fragile and where COVID-19 may provide the opportunity for corruption, incompetence, and exclusive or repressive behaviour by elites. However, the long-term implications are not yet clear, and as one report stated, caution should be exercised in drawing conclusions at this stage in the crisis. ${ }^{23}$

- Leadership was mentioned in the reviews as making the difference between policy success and failure. However, more than individual leaders, it is the political systems that shape leadership that are of importance. Good outcomes often reflect good political processes rather than simply good leaders, which links with the review on PFM systems. Such systems should enable leaders to test, learn, and adapt, to admit failure, to learn lessons, and to allow them to change course. ${ }^{24}$

- One K4D report considers potential geopolitical changes and challenges in the region of Eastern Africa. It concludes that the pandemic is likely to lead to countries re-evaluating their

\footnotetext{
${ }^{19}$ One report also looked at the implications for state-owned enterprises during crisis with responses often resulting in higher costs and reduced profits or losses. See more in HDR865 "State Owned Enterprises and Public Finances in Developing Countries: The Impact of Economic and Health-related Crises" by Kelbesa Megersa.

20 The focus areas of PFM reforms are mainly risk management (e.g. through control of the fiscal balance and aggregate spending), allocative efficiency (e.g. through prioritisation of expenditure), effectiveness and efficiency of expenditure (e.g. through value-for-money measures), and financial management transparency (e.g. through web-based systems and awareness programmes).

21 See HDR810 "Lessons from Public Financial Management (PFM) Reforms After a Financial Crisis" by Evertjan Quak.

22 See HDR809 "Tax Reforms After COVID-19 and Financial Crises” by Kelbesa Megersa.

${ }^{23}$ See EI34 "COVID-19, governance, and conflict: emerging impacts and future evidence needs" by Sian Herbert and Heather Marquette.
}

24 See more on leadership and politics in HDR756 "Secondary impacts of major disease outbreaks in low- and middle-income countries" by Brigitte Rohwerder and EI34 "COVID-19, governance, and conflict: emerging impacts and future evidence needs" by Sian Herbert and Heather Marquette. 
relationships with neighbouring countries and further afield as they seek financial help from abroad (e.g. debt relief), ${ }^{25}$ and to build more resilience to global shocks. There is no evidence on the specific effect of COVID-19 on regional conflicts or border disputes between states. ${ }^{26}$

\section{Social inclusion of women and girls}

- Due to the lack of empirical evidence from the pandemic, the K4D reports relied on evidence based on previous epidemics or health crisis. Based on that, the reports show that there is strong evidence to suggest that women and girls suffer from extreme and multifaceted negative secondary impact as a result of health crises. This includes higher poverty rates, increase in unplanned pregnancies, a surge in school dropout rates and child labour of adolescent girls, loss of income and reduced financial empowerment, increased household work, reduced access to healthcare and WASH alongside increased maternal deaths, greater food insecurity and malnutrition. ${ }^{27}$

- Because of the pandemic's impact on women and girls, participation of women and women's rights organisations in senior decision-making processes related to the responses to the pandemic is recommended. However, one K4D report shows that this often does not happen (in all countries around the world). One significant challenge in the delivery of a gendered COVID-19 response is the lack of age and gender disaggregated data. Due to limited evidence from the COVID-19 pandemic, research from other emergency responses, shows that women and women's rights organisations are more likely to understand and address the specific needs of women, particularly in relation to gender-based violence. ${ }^{28}$

- Overall, the potential increase in gender inequality could reduce the ground gained over the past decade, particularly related to access to justice, employment (for example due to higher care burden by women or job losses in sectors that are hit harder for women) ${ }^{29}$ and girls' education. ${ }^{30}$

\footnotetext{
25 The need for aid and debt relief from the economic downturn may lead East African states to reconfigure their relationships with the rest of the world.

${ }^{26}$ See more in HDR846 "Immediate and longer-term impacts of COVID-19 on geopolitics in East Africa" by Luke Kelly.

27 See in EI35 "COVID-19 and Social Development" by Brigitte Rohwerder and for Sub-Saharan Africa in HDR830 "The Secondary Impacts of COVID-19 on Women and Girls in Sub-Saharan Africa" by Tal Rafaeli and Geraldine Hutchinson.

28 See HDR850 "COVID-19 and the participation of women and women's rights organisations in decision-making" by Lina Aghajanian and Ella Page.

29 See a dedicated section on gender inequalities, employment and COVID-19 in EI35 "COVID-19 and Social Development" by Brigitte Rohwerder. On women employment in GVCs a specific report shows that women are in the short term more likely to lose their jobs in labour intensive manufacturing such as garment sectors as global demand drop. These women often work from their own homes and are particularly vulnerable to supply and demand shocks, losing income as a result of the COVID-19 pandemic. Additionally, many of these women in the informal sector do not qualify for government support. See EI43 "COVID-19, Global Value Chains, and the impact on gender" by Keir MacDonald.
}

30 See some aspects on girls' education in HDR793 "What evidence exist regarding efforts to mitigate the secondary impact of past disease outbreaks and associated response on the education sector?" by Joe Hallgarten and EI35 "COVID-19 and Social Development" by Brigitte Rohwerder. 
- School closures place girls at increased risk of child marriage and falls in household income, as a result of the economic impacts of COVID-19, can also lead to the marriage of adolescent girls being perceived by parents or caregivers as a way to reduce the household burden, or a means to earn income or access loans in informal dowry-based economies. ${ }^{31}$ For the same reasons (school closure and higher levels of poverty) child labour could increase, as is the experience of previous epidemics and financial crises. ${ }^{32}$

\section{Conclusions}

- Although not exhaustively, the requests from FCDO for K4D services during the pandemic cover many important indirect impacts of the COVID-19 crisis that need to be considered and addressed in development approaches, programming, policies, strategies, and diplomacy.

- The pandemic might have shifted development priorities and shows that short-term responses need to be linked with longer term outcomes to ensure increased resilience and inclusiveness, and environmental sustainability.

- This report shows the interrelationship between the indirect impacts of COVID-19 which needs coherent, interdisciplinary responses. Linking the different knowledge insights in an accessible way between teams is important, not only between multiple cadres, but also between programme, research, evaluation, policy and diplomacy departments.

- K4D's requested outputs show the necessity of a transformative "Building Back Better" agenda that accepts uncertainty and deals with the interconnectedness between challenges and does not address problems in siloes. This includes the support for marginalised groups (e.g. women, youth, minorities, people with disabilities) and piloting innovative ways of doing things differently, which are not necessarily expansive approaches, but could be complex. Context specific, gender-sensitive, and conflict-sensitive analysis is pivotal to make the right evidence-based decisions and choices.

- The K4D service provided timely evidence, donor insights, and literature overviews during the current global health (and economic) crisis, not only to support FCDO offices in-country and in Whitehall, but (because most of the K4D output is publicly available) also for other organisations. The uptake and citation of so many of the K4D reports on the pandemic's indirect impacts show the need for such knowledge, based on the reputation of K4D and the quality of the outputs.

\footnotetext{
${ }^{31}$ See more in EI35 "COVID-19 and Social Development" by Brigitte Rohwerder.

${ }^{32}$ More in HDR819 "Impact of COVID-19 on child labour in South Asia" by Iffat Idris.
} 


\section{Annex: List of K4D resources on indirect COVID-19 impacts}

\begin{tabular}{|c|c|c|c|c|c|c|c|c|c|}
\hline $\begin{array}{l}\text { Main } \\
\text { Category }\end{array}$ & Report & $\begin{array}{l}\text { Learning } \\
\text { products }\end{array}$ & $\begin{array}{l}\text { Request } \\
\text { type }\end{array}$ & Title & Published & $\begin{array}{l}\text { FCDO } \\
\text { purpose }\end{array}$ & $\begin{array}{l}\text { Geographical } \\
\text { scope }\end{array}$ & $\begin{array}{l}\text { Focus } \\
\text { countries }\end{array}$ & Cadre team \\
\hline \multirow[t]{9}{*}{ Health } & HDR825 & & $\begin{array}{l}\text { Literature } \\
\text { overview }\end{array}$ & Maternal and sexual reproductive health situation in Tanzania & Yes & Programme & Africa & Tanzania & Health \\
\hline & HDR1007 & & Analytical & $\begin{array}{l}\text { Protecting and promoting systems for essential health } \\
\text { services during rollout of COVID-19 tools }\end{array}$ & Yes & $\begin{array}{l}\text { Emerging } \\
\text { issues }\end{array}$ & LMICs & & Health \\
\hline & El41 & 1 policy brief & $\begin{array}{l}\text { Evaluation } \\
\text { \& Lessons } \\
\text { learned }\end{array}$ & $\begin{array}{l}\text { Addressing NCDs during COVID-19 and beyond: implications } \\
\text { for the Better Health Programme }\end{array}$ & $\begin{array}{l}\text { Policy } \\
\text { Brief only }\end{array}$ & Programme & MICs & & Other (PF) \\
\hline & $\begin{array}{l}\text { LJ output } \\
\text { summary }\end{array}$ & & $\begin{array}{l}\text { Overview } \\
\text { of literature }\end{array}$ & Health System Strengthening & Yes & $\begin{array}{l}\text { Emerging } \\
\text { issues }\end{array}$ & LMICs & & Health \\
\hline & HDR836 & & $\begin{array}{l}\text { Donor } \\
\text { practice }\end{array}$ & $\begin{array}{l}\text { Enhancing insights into indirect health impacts of previous } \\
\text { health emergencies and COVID-19 in Africa. }\end{array}$ & No & Policy & Africa & & Health \\
\hline & HDR955 & & Analytical & Social inclusion and immunisation & Yes & Programme & LMICs & & $\begin{array}{l}\text { Other } \\
\text { (Disability } \\
\text { Inclusion } \\
\text { team) }\end{array}$ \\
\hline & HDR837 & & $\begin{array}{l}\text { Donor } \\
\text { practice }\end{array}$ & $\begin{array}{l}\text { Enhancing insights into indirect health impacts of previous } \\
\text { health emergencies and COVID-19 in LMICs. }\end{array}$ & No & Policy & LMICs & & Health \\
\hline & HDR756 & & Analytical & $\begin{array}{l}\text { Secondary impacts of major disease outbreaks in low- and } \\
\text { middle-income countries }\end{array}$ & Yes & $\begin{array}{l}\text { Emerging } \\
\text { issues }\end{array}$ & LMICs & & Humanitarian \\
\hline & HES & $\begin{array}{l}1 \text { online } \\
\text { search engine }\end{array}$ & $\begin{array}{l}\text { Overview } \\
\text { of literature }\end{array}$ & COVID-19 Health Evidence Summaries & Yes & $\begin{array}{l}\text { Emerging } \\
\text { issues }\end{array}$ & LMICs & & Health \\
\hline
\end{tabular}




\begin{tabular}{|c|c|c|c|c|c|c|c|c|c|}
\hline \multirow[t]{4}{*}{ Water } & HDR826 & & Analytical & Water for the Urban Poor and COVID-19 & Yes & Programme & LMICs & & $\begin{array}{l}\text { Climate and } \\
\text { Environment }\end{array}$ \\
\hline & HDR969 & & Analytical & $\begin{array}{l}\text { WASH in schools for student return during the COVID-19 } \\
\text { pandemic }\end{array}$ & Yes & Programme & LMICs & & Education \\
\hline & $\begin{array}{l}\text { LJ output } \\
\text { overview }\end{array}$ & & $\begin{array}{l}\text { Overview } \\
\text { of literature }\end{array}$ & Water Security & Yes & $\begin{array}{l}\text { Support } \\
\text { Learning } \\
\text { Journey }\end{array}$ & LMICs & & $\begin{array}{l}\text { Climate and } \\
\text { Environment }\end{array}$ \\
\hline & HDR803 & $\begin{array}{l}2 \text { opinion } \\
\text { pieces }\end{array}$ & Analytical & $\begin{array}{l}\text { Water System Preparation for a Projected Increase in } \\
\text { Pandemics }\end{array}$ & Yes & $\begin{array}{l}\text { Emerging } \\
\text { issues }\end{array}$ & LMICs & & $\begin{array}{l}\text { Climate and } \\
\text { Environment }\end{array}$ \\
\hline \multirow[t]{6}{*}{ Economy } & HDR874 & 1 slide pack & Analytical & $\begin{array}{l}\text { The COVID-19 pandemic and the future of Global Value } \\
\text { Chains (GVCs) }\end{array}$ & Yes & Programme & MICs & & Other (PF) \\
\hline & HDR811 & 1 slide pack & Analytical & $\begin{array}{l}\text { Impacts of COVID-19 on Inclusive Economic Growth in } \\
\text { Middle-income Countries }\end{array}$ & Yes & $\begin{array}{l}\text { Emerging } \\
\text { issues }\end{array}$ & MICs & & Other (PF) \\
\hline & HDR956 & & Analytical & $\begin{array}{l}\text { COVID-19 impact on employment and skills for the labour } \\
\text { market }\end{array}$ & Yes & Programme & MICs & $\begin{array}{l}\text { Mexico, } \\
\text { Malaysia, } \\
\text { Indonesia, } \\
\text { Philippines } \\
\text { and South } \\
\text { Africa }\end{array}$ & Other (PF) \\
\hline & HDR957 & & Analytical & $\begin{array}{l}\text { How can middle-income countries improve their skills systems } \\
\text { post-COVID-19? }\end{array}$ & Yes & Programme & MICs & & Other (PF) \\
\hline & HDR974 & & Analytical & Economic impact of local vaccine manufacturing & Yes & Policy & LMICs & $\begin{array}{l}\text { India, } \\
\text { Indonesia, } \\
\text { Thailand, } \\
\text { Brazil, } \\
\text { Cuba, } \\
\text { Mexico }\end{array}$ & $\begin{array}{l}\text { Other (British } \\
\text { Embassy } \\
\text { Senegal) }\end{array}$ \\
\hline & $\begin{array}{l}\text { HDR815- } \\
816\end{array}$ & & Analytical & $\begin{array}{l}\text { Impacts of COVID-19 regulatory measures on small-scale and } \\
\text { informal trade in Zimbabwe }\end{array}$ & Yes & $\begin{array}{l}\text { Emerging } \\
\text { issues }\end{array}$ & Africa & Zimbabwe & Livelihoods \\
\hline
\end{tabular}




\begin{tabular}{|c|c|c|c|c|c|c|c|c|c|}
\hline & HDR890 & & Analytical & The Informal Sector and COVID-19 & Yes & $\begin{array}{l}\text { Emerging } \\
\text { issues }\end{array}$ & Africa & & Livelihoods \\
\hline & $E I 35$ & $\begin{array}{l}1 \text { infographic } \\
\text { and } 1 \text { slide } \\
\text { pack }\end{array}$ & Analytical & COVID-19 and Social Development & Yes & $\begin{array}{l}\text { Emerging } \\
\text { issues }\end{array}$ & LMICs & & $\begin{array}{l}\text { Social } \\
\text { Development }\end{array}$ \\
\hline & $\begin{array}{l}\text { LJ } \\
\text { Summary } \\
\text { report }\end{array}$ & & $\begin{array}{l}\text { Evaluation } \\
\text { \& Lessons } \\
\text { Learned }\end{array}$ & & No & $\begin{array}{l}\text { Support } \\
\text { Learning } \\
\text { Journey }\end{array}$ & MICs & & Other (PF) \\
\hline & HDR756 & & Analytical & $\begin{array}{l}\text { Secondary impacts of major disease outbreaks in low- and } \\
\text { middle-income countries }\end{array}$ & Yes & $\begin{array}{l}\text { Emerging } \\
\text { issues }\end{array}$ & LMICs & & Humanitarian \\
\hline & HDR971 & & Analytical & The economic impact of COVID-19 in Colombia & Yes & $\begin{array}{l}\text { Emerging } \\
\text { issues }\end{array}$ & Latin America & Colombia & Other (PF) \\
\hline $\begin{array}{l}\text { Governance } \\
\text { \& Conflict }\end{array}$ & HDR808 & & Analytical & $\begin{array}{l}\text { The COVID-19 pandemic and response on violent extremist } \\
\text { recruitment and radicalisation }\end{array}$ & Yes & Programme & LMICs & & Conflict \\
\hline & HDR809 & & Analytical & Tax Reforms After COVID-19 and Financial Crises & Yes & $\begin{array}{l}\text { Test } \\
\text { assumption }\end{array}$ & LMICs & & Economics \\
\hline & HDR865 & & Analytical & $\begin{array}{l}\text { State Owned Enterprises and Public Finances in Developing } \\
\text { Countries: The Impact of Economic and Health-related Crises }\end{array}$ & Yes & $\begin{array}{l}\text { Emerging } \\
\text { issues }\end{array}$ & LMICs & & Governance \\
\hline & HDR810 & & Analytical & $\begin{array}{l}\text { Lessons from Public Financial Management (PFM) Reforms } \\
\text { After a Financial Crisis }\end{array}$ & Yes & $\begin{array}{l}\text { Test } \\
\text { assumption }\end{array}$ & LMICs & & Economics \\
\hline & HDR756 & & Analytical & $\begin{array}{l}\text { Secondary impacts of major disease outbreaks in low- and } \\
\text { middle-income countries }\end{array}$ & Yes & $\begin{array}{l}\text { Emerging } \\
\text { issues }\end{array}$ & LMICs & & Humanitarian \\
\hline
\end{tabular}




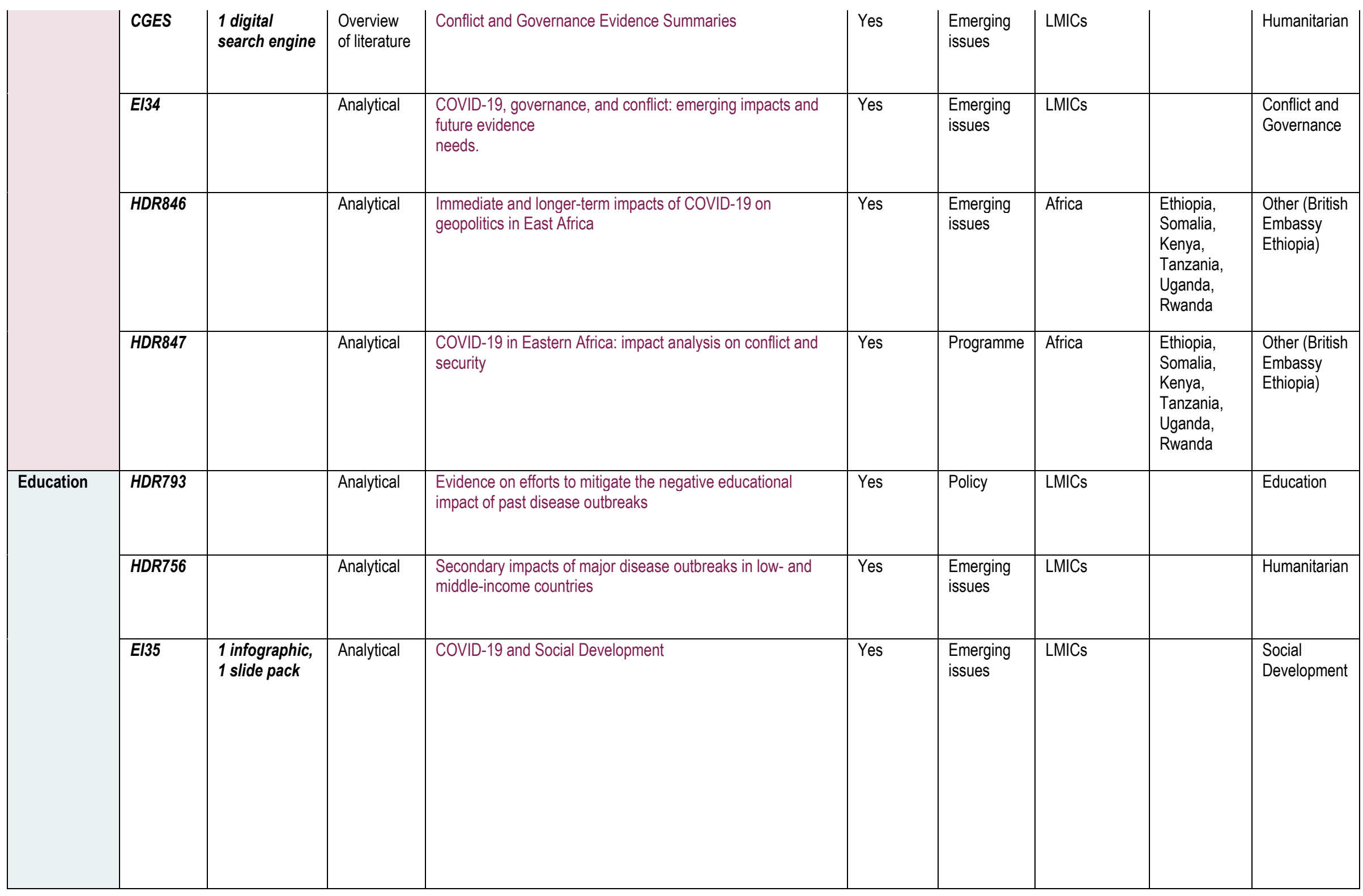




\begin{tabular}{|c|c|c|c|c|c|c|c|c|c|}
\hline \multirow[t]{8}{*}{$\begin{array}{l}\text { Social } \\
\text { inclusion }\end{array}$} & HDR806 & & $\begin{array}{l}\text { Evaluation } \\
\text { \& Lessons } \\
\text { learned }\end{array}$ & Girl-focused life skills interventions at a distance & Yes & $\begin{array}{l}\text { Emerging } \\
\text { issues }\end{array}$ & LMICs & & Education \\
\hline & HDR807 & & Analytical & $\begin{array}{l}\text { The links between girls' life skills intervention in emergencies } \\
\text { and their return to education post-crisis and prevention of } \\
\text { unwanted pregnancies and early marriage }\end{array}$ & Yes & $\begin{array}{l}\text { Emerging } \\
\text { issues }\end{array}$ & LMICs & & Education \\
\hline & HDR819 & & Analytical & Impact of COVID-19 on child labour in South Asia & Yes & Programme & Asia & $\begin{array}{l}\text { Afghanistan, } \\
\text { Bangladesh, } \\
\text { India, } \\
\text { Myanmar, } \\
\text { Nepal and } \\
\text { Pakistan }\end{array}$ & $\begin{array}{l}\text { Social } \\
\text { Development }\end{array}$ \\
\hline & $E I 35$ & $\begin{array}{l}1 \text { infographic, } \\
1 \text { slide pack }\end{array}$ & Analytical & COVID-19 and Social Development & Yes & $\begin{array}{l}\text { Emerging } \\
\text { issues }\end{array}$ & LMICs & & $\begin{array}{l}\text { Social } \\
\text { Development }\end{array}$ \\
\hline & HDR830 & & Analytical & $\begin{array}{l}\text { The Secondary Impacts of COVID-19 on Women and Girls in } \\
\text { Sub-Saharan Africa }\end{array}$ & Yes & $\begin{array}{l}\text { Emerging } \\
\text { issues }\end{array}$ & Africa & & $\begin{array}{l}\text { Social } \\
\text { Development }\end{array}$ \\
\hline & HDR850 & & Analytical & $\begin{array}{l}\text { COVID-19 and the participation of women and women's rights } \\
\text { organisations in decision-making }\end{array}$ & Yes & $\begin{array}{l}\text { Test } \\
\text { assumption }\end{array}$ & LMICs & & Conflict \\
\hline & El43 & & Analytical & $\begin{array}{l}\text { COVID-19, Global Value Chains, and the Impact on Gender: } \\
\text { Evidence from the Garment and Electronics Sectors in Asia }\end{array}$ & Yes & $\begin{array}{l}\text { Emerging } \\
\text { issues }\end{array}$ & Asia & & Other (PF) \\
\hline & HDR908 & & Analytical & COVID 19 and the rights of belief minorities & Yes & $\begin{array}{l}\text { Research } \\
\text { programme }\end{array}$ & LMICs & & $\begin{array}{l}\text { Other } \\
\text { (Human } \\
\text { Rights and } \\
\text { Democracy) }\end{array}$ \\
\hline
\end{tabular}




\begin{tabular}{|c|c|c|c|c|c|c|c|c|c|}
\hline & HDR955 & & Analytical & Social inclusion and immunisation & Yes & Programme & LMICs & & $\begin{array}{l}\text { Other } \\
\text { (Disability } \\
\text { Inclusion } \\
\text { team) }\end{array}$ \\
\hline & HDR756 & & Analytical & $\begin{array}{l}\text { Secondary impacts of major disease outbreaks in low- and } \\
\text { middle-income countries }\end{array}$ & Yes & $\begin{array}{l}\text { Emerging } \\
\text { issues }\end{array}$ & LMICs & & Humanitarian \\
\hline \multirow[t]{9}{*}{ Interventions } & HDR828 & & Analytical & COVID-19's impact on achieving 'Secondary Benefits' & Yes & Policy & MICs & & Other (PF) \\
\hline & HDR827 & & $\begin{array}{l}\text { Evaluation } \\
\text { \& Lessons } \\
\text { learned }\end{array}$ & The changing perspectives on 'Secondary Benefits' & Yes & Policy & MICs & & Other (PF) \\
\hline & HDR975 & 1 slide pack & $\begin{array}{l}\text { Evaluation } \\
\text { \& Lessons } \\
\text { learned }\end{array}$ & $\begin{array}{l}\text { Trade facilitation to promote international trade in green } \\
\text { technologies }\end{array}$ & Yes & Programme & MICs & & Other (PF) \\
\hline & HDR976 & & Analytical & Impacts of trade facilitation on carbon emissions & Yes & Programme & MICs & & Other (PF) \\
\hline & El35 & $\begin{array}{l}1 \text { infographic, } \\
1 \text { slide pack) }\end{array}$ & Analytical & COVID-19 and Social Development & Yes & $\begin{array}{l}\text { Emerging } \\
\text { issues }\end{array}$ & LMICs & & $\begin{array}{l}\text { Social } \\
\text { Development }\end{array}$ \\
\hline & $E / 39$ & & Analytical & $\begin{array}{l}\text { Linking Business Environment Reform with Gender and } \\
\text { Inclusion: A Study of Business Licensing Reform in Indonesia }\end{array}$ & Yes & Programme & MICs & Indonesia & Other (PF) \\
\hline & HDR877 & 1 slide pack & Analytical & $\begin{array}{l}\text { Factors influencing inclusive economic resilience in middle- } \\
\text { income countries }\end{array}$ & Yes & $\begin{array}{l}\text { Emerging } \\
\text { issues }\end{array}$ & MICs & & Other (PF) \\
\hline & HDR980 & & $\begin{array}{l}\text { Donor } \\
\text { practice }\end{array}$ & Global evaluations of the response to COVID-19 & No & $\begin{array}{l}\text { Emerging } \\
\text { issues }\end{array}$ & LMICs & & Evaluation \\
\hline & HDR757 & & Analytical & $\begin{array}{l}\text { Evidence and lessons on efforts to mitigate the secondary } \\
\text { impact of past disease outbreaks and associated response } \\
\text { and control measures }\end{array}$ & Yes & $\begin{array}{l}\text { Emerging } \\
\text { issues }\end{array}$ & LMICs & & Humanitarian \\
\hline
\end{tabular}




\begin{tabular}{|c|c|c|c|c|c|c|c|}
\hline $\begin{array}{l}\text { LJ } \\
\text { summary } \\
\text { report }\end{array}$ & & $\begin{array}{l}\text { Evaluation } \\
\text { \& Lessons } \\
\text { learned }\end{array}$ & & No & $\begin{array}{l}\text { Support for } \\
\text { Learning } \\
\text { Journey }\end{array}$ & MICs & Other (PF) \\
\hline HDR812 & 1 slide pack & Analytical & $\begin{array}{l}\text { Mitigating the economic impacts of epidemics and financial } \\
\text { crises: Focus on middle-income countries. }\end{array}$ & Yes & $\begin{array}{l}\text { Emerging } \\
\text { issues }\end{array}$ & MICs & Other (PF) \\
\hline
\end{tabular}




\section{Suggested citation}

Quak, E. (2021). K4D's Work on the Indirect Impacts of Covid-19 in Low- and Middle-Income Countries. K4D Helpdesk Report No. 1018. Brighton, UK: Institute of Development Studies. DOI: 10.19088/K4D.2021.093

\section{About this report}

This report is based on nine days of desk-based research. The K4D research helpdesk provides rapid syntheses of a selection of recent relevant literature and international expert thinking in response to specific questions relating to international development. For any enquiries, contact helpdesk@k4d.info.

K4D services are provided by a consortium of leading organisations working in international development, led by the Institute of Development Studies (IDS), with Education Development Trust, Itad, University of Leeds Nuffield Centre for International Health and Development, Liverpool School of Tropical Medicine (LSTM), University of Birmingham International Development Department (IDD) and the University of Manchester Humanitarian and Conflict Response Institute (HCRI).

This report was prepared for the UK Government's Foreign, Commonwealth \& Development Office (FCDO) and its partners in support of pro-poor programmes. Except where otherwise stated, it is licensed for non-commercial purposes under the terms of the Open Government Licence v3.0. K4D cannot be held responsible for errors or any consequences arising from the use of information contained in this report. Any views and opinions expressed do not necessarily reflect those of $F C D O, K 4 D$ or any other contributing organisation.

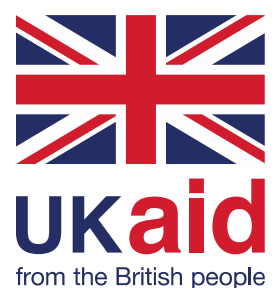

(c) Crown copyright 2021. 